\section{Danko Zelić}

Institut za povijest umjetnosti, Zagreb

Izvorni znanstveni rad / Original scientific paper UDK / UDC: 728.1.025.4(497.5 Dubrovnik)"15"

29. 11. 2013.

\section{Dva požara, dvije obnove, dva stila: prilog poznavanju dubrovačke stambene arhitekture sredinom 16. stoljeća}

Ključne riječi: Dubrovnik, urbanizam, arhitektura, požari, gotika, renesansa, općinske kuće, Jakov de Spinis, Andrijići Keywords: Dubrovnik, urban development, architecture, fires, Gothic, Renaissance, Andrijić stonemasons family

U tekstu se analiziraju vijesti o obnovama jedne privatne i jedne općinske kuće u najužem središtu Dubrovnika u šestom desetljeću 16. stoljeća - kući braće Babalio, na uglu ulica Lučarice i Od puča, i četortom bloku općinskih kuća na istočnom dijelu sjevernog pročelja Place.

Dva zahvata povezuju činjenice da su im povod bili požari i da je u njima sudjelovao naturalizirani francuski klesar i kipar Jakov de Spinis iz Orléansa, a razlikuje odabir arhitektonskog vokabulara na pročeljima - u proom slučaju iz gotičkog, u drugom iz renesansnog repertoara. U razmatranju obnove kuće braće Babalio (1552.), upozorava se na dosad neuočeni podatak o požaru te kuće u ljetopisu Nikše Ragnine, a zahvat na obnovi četvrtog bloka općinskih kuća (1559.-1561.) pokušava se, osim u svjetlu arhivskih dokumenata, interpretirati na osnovi tragova do danas sačuvanih na njegovu pročelju, ali i dragocjenoga vizualnog izvora - vedute grada prije potresa koju je nedavno nabavilo i dalo restaurirati Društvo prijatelja dubrovačke starine.

Požari su neprijeporno kapitalni događaji u povijesti gradogradnje srednjovjekovnog Dubrovnika; dovoljno je spomenuti samo dva najrazornija, gotovo mitskih razmjera - onaj 1296. godine, kojemu neposredno slijedi donošenje urbanističkog plana za sjeverni dio grada, ${ }^{1}$ i požar 1370 . poslije kojega se, vjerujemo li predajama koje su prenijeli lokalni ljetopisci, pomišljalo napustiti Dubrovnik te izgraditi grad iznova na nekom prikladnijem mjestu. ${ }^{2}$ I požari su tako, naizgled paradoksalno, na svoj način pridonosili urbanističkoj sistematizaciji Grada; nije li znakovito da se podjela urbanog prostora na seksterije prvi put u izvorima izričito spominje upravo u zakonskom propisu o obrani od požara iz 1309. godine? ${ }^{3}$ Poslije 1370., kada je uvođenjem stabilne evidencije nekretnina u općinskom vlasništvu dan odlučujući impuls iskorjenjivanju drvenih kuća, ${ }^{4}$ sve do vatrene stihije koja će 1667. razoriti grad više od velikog potresa koji joj je neposredno prethodio, požari će ostati stalnim pratiteljima dubrovačke svakodnevice, ${ }^{5}$ ne izazivajući više promjene u urbanističkoj strukturi, nego ponajprije u arhitekturi grada. $\mathrm{U}$ obnovama koje su slijedile donosile su se odluke o tome hoće li se građevine restaurirati ili osuvremeniti, kako na planu funkcija tako i arhitektonskog oblikovanja; od gabarita do detalja arhitektonske opreme. U dovršenom, kamenim kućama tijekom 15. stoljeća izgrađenom "gotičkom" gradu, požari su nerijetko bili povodi pojavi arhitektonskih oblika u kojima će stoljećima kasnije biti raspoznata oblikovna, a potom i strukturalna obilježja renesansnog stila. Naročito su u tom pogledu paradigmatične dvije obnove Kneževa dvora u 15. stoljeću, poslije požara izazvanih eksplozijama baruta 1435. i 1463. godine. U tom, razmjerno kratkom vremenu dvaput je redefiniran složen arhitektonski program unutrašnjosti ali i koncepcija vanjštine zdanja, a u prvoj od tih obnova - kao što je utvrdila Nada Grujić - u monumentalnoj javnoj arhitekturi grada prvi će se put javiti arhitektonski oblici allantica. ${ }^{6}$

Dvije obnove kuća sredinom 16. stoljeća koje su tema ovog priloga izazvane su upravo požarima. Polazeći od arhivskih 


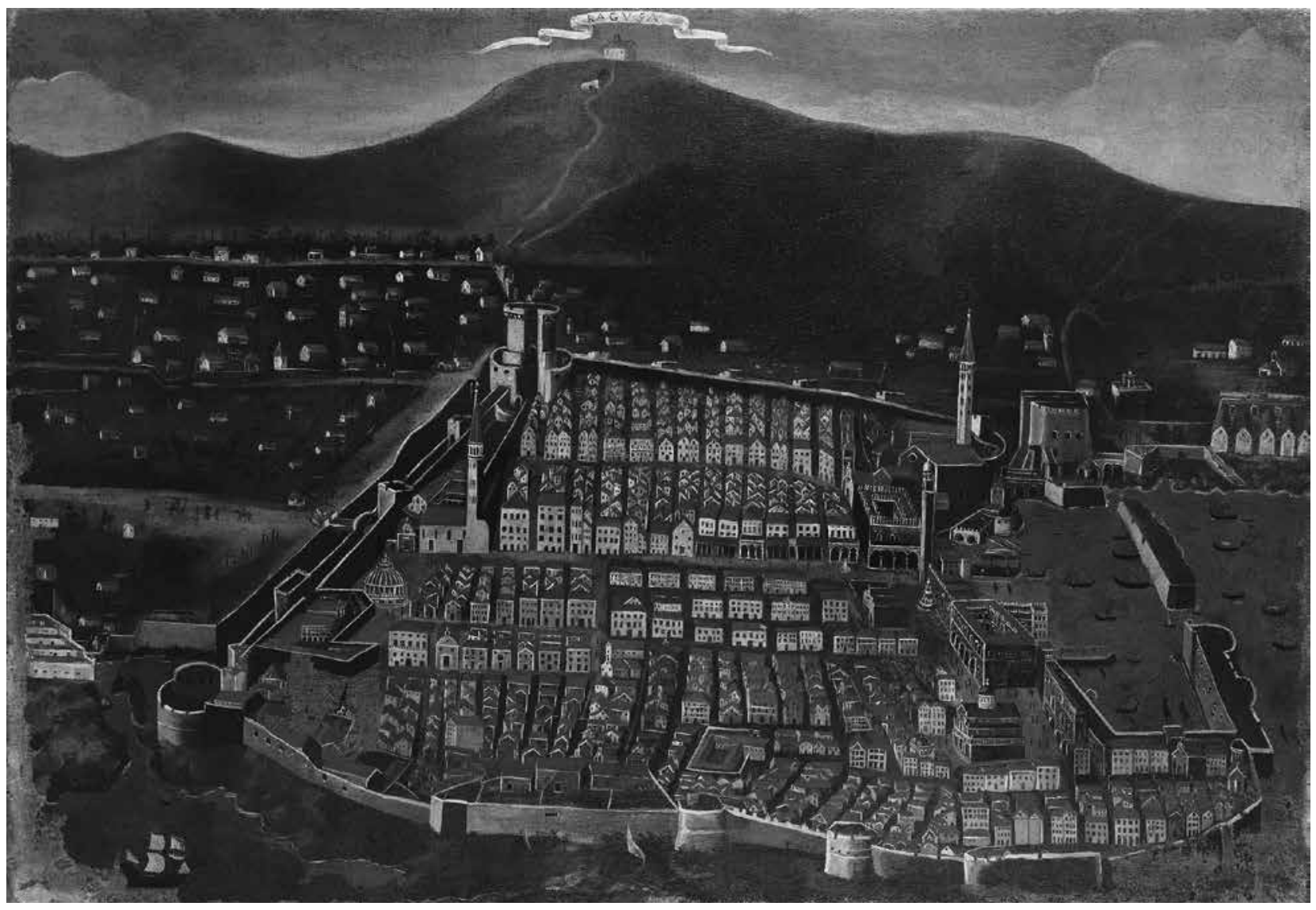

1. Veduta Dubrovnika prije potresa 1667., Društvo prijatelja dubrovačke starine, Dubrovnik (foto: D. Vokić) / Veduta of Dubrovnik before the earthquake of 1667, Društvo prijatelja dubrovačke starine [Society of the Friends of Ancient and Historical Dubrovnik]

vijesti na koje je prije točno 66 godina upozorio Cvito Fisković, moguće je, nažalost, raspravljati uglavnom o obnovama njihovih pročelja. Unatoč činjenici da im je glavni protagonist bio Jakov Spinis iz Orléansa, francuski klesar nastanjen u Dubrovniku, ${ }^{8}$ većje Cvito Fisković istaknuo ono što sačuvani dokumenti nedvosmisleno pokazuju: da su krajnji rezultat u oba zahvata bila u oblikovnom smislu homogena pročelja - u prvom slučaju gotičko, u drugom renesansno. ${ }^{9}$ Dok je o prvoj obnovi moguće raspravljati tek na osnovi pisanih svjedočanstva, za interpretaciju drugog zahvata pokazatelje $\mathrm{u}$ arhivskim zapisima moguće je nadopuniti analizom sačuvanih arhitektonskih struktura, ali i dragocjenoga vizualnog izvora - vedute grada prije potresa koju je nedavno nabavilo Društvo prijatelja dubrovačke starine (sl. 1). Poslije pomnog zahvata restauratora Denisa Vokića postalo je naime bjelodano da taj "portret" Dubrovnika brojem i vjerodostojnošću vizualnih podataka daleko nadilazi sve druge srodne prikaze. ${ }^{10}$

\section{Kuća braće Babalio 1552. godine}

Jakov Spinis se 14. kolovoza 1552. obvezao Juniju Mihovu Babaliju (Babalio; Bobalić, Bobaljević) isporučiti kamene okvire devet prozora za pročelje kuće koju je taj zajedno s braćom posjedovao u seksteriju sv. Vlaha - šest prozora oblikom i dimenzijama jednakih prozorima na pročelju Kneževa dvora, triforu širine oko 3 i visine oko $5 \mathrm{~m}$ te dvije jednako visoke monofore [Prilog - dokument I] ${ }^{11} \mathrm{U}$ ugovoru se kao predlošci za tri najveća prozora spominju trifora i monofore na kući Junija Mihova Bone. Naručene su i četiri dvostruke konzole koje će biti ugrađene ispod trifore. Mjere su im primjerene njezinim, uistinu impozantnim, dimenzijama: kamene grede trebale su biti kvadratnog presjeka, sa stranicom od $0,5 \mathrm{~m}$, s dužim dijelovima (modionos principales) duljine oko $3 \mathrm{~m}$, te proporcionalno dugim kraćim dijelovima (modionos bastardis). Za ugradnju ispod velikih monofora naručene su dvije kamene ploče duljinom jednake širini prozora, a širinom debljini zida uvećanoj za oko $0,5 \mathrm{~m}$, koliko su trebale biti istaknute u prostor ulice.

Prozori Kneževa dvora koji se navode kao predlošci za šest manjih prozora zacijelo nisu velike bifore nad lukovima pročelnog trijema (klesane 1439. prema nacrtima Petra Martinova i Onofrija della Cave); ${ }^{12}$ vjerojatnije je riječ o manjim gotičkim monoforama niskoga prvog kata (mezanina) na glavnom pročelju, točnije na zidu trijema Dvora. Osim činjenice da je također bila u seksteriju sv. Vlaha, možda 
čak u istoj ulici - Od puča, ${ }^{13}$ o građevini na kojoj su se nalazili prozori navedeni kao predlošci za triforu i dvije velike monofore zasad nemamo drugih spoznaja. ${ }^{14} \mathrm{Za} \mathrm{kulturnu} \mathrm{je}$ povijest, međutim, važan podatak da je u toj kući, na piru Junija Mihova Bone, vršnjaka (i imenjaka) Junija Mihova Babalija, koji je ženidbeni ugovor sklopio iste, 1552. godine, bila (pra)izvedena Držićeva komedija Pjerin. ${ }^{15}$

Još je od Cvite Fiskovića činjenica da se sredinom 16. stoljeća za jednu od gradskih kuća naručuju isključivo gotički prozori isticana kao svojevrstan kuriozum, pokazatelj i potvrda dugovječnosti gotičkog stila u stambenoj arhitekturi Dubrovnika. ${ }^{16}$ Razlozi »dugom trajanju " gotičkih oblika u povijesnoumjetničkoj su historiografiji pronalaženi u njihovu simboličkom "sadržaju", točnije konotacijama (poput starosti, tradicije, plemenitosti) koje su imali za naručitelje, potom u činjenici da su procesi naručivanja, ugovaranja i izrade klesane arhitektonske dekoracije u svojim različitim pravnim i tehnološkim aspektima pogodovali ugledanju na postojeće oblike, sve do interpretacija prema kojima se i u stambenoj arhitekturi, kada su naručitelji bili vlastela, iskazivala poslovična konzervativnost dubrovačke sredine.

Odgovor na pitanje što je bilo odlučujuće za odabir arhitektonskog vokabulara na pročeljima zacijelo bi u svakom pojedinom slučaju uključivao ponešto od svega navedenoga. Kada je riječ o kući braće Babalio, posrijedi je najvjerojatnije bila restauracija starijeg pročelja. U prilog tomu govori dosad neuočen podatak da je kuća nedugo prije izgorjela. Požar kuće braće Junija, Lovra i Andrije, sinova Miha Babalija, u svojim je analima zabilježio suvremenik (vjerojatno i očevidac) toga događaja, pjesnik i povjesničar Nikša Ragnina. ${ }^{17}$ Osim točnog dana, datuma i vremena izbijanja požara - srijede, 18. travnja 1552. u četvrtom noćnom satu - iz Ragninina zapisa doznajemo i položaj kuće: na uglu Crevljarske (današnje ulice Od puča) i ulice Lučarice. Vatra se pojavila na prvom katu, gdje se - budući da se kao neposredan uzrok navodi priprema konfeta za svadbeni pir Andrije, jednog od trojice braće - najvjerojatnije nalazila kuhinja. Plamen je progutao trgovačku robu, svilu i sukno, te sve predmete kućanstva. ${ }^{18}$

Premda taj požar nije jedini o kojem pišu lokalni ljetopisci, znatnijih je požara u gradu 16. stoljeća bilo više no što su ih oni evidentirali. ${ }^{19}$ Stoga se valja zapitati koji su motivi Ragninu naveli da za potomstvo zabilježi upravo požar kuće braće Babalio, a potom i po kojim su to "historiografskim" kriterijima dubrovački ljetopisci odabirali kojim će požarima "dati riječ". Prvi je razlog, pretpostavljamo, u činjenici da su braća Babalio pripadali ne samo najužoj političkoj elitii ${ }^{20}$ nego i krugu od nekoliko najimućnijih Dubrovčana svoga doba. Bavili su se tzv. kreditnom trgovinom, a u svjetlu pokazatelja o vrijednosti njihovih poslova (između 1550. i 1572. registrirane su zadužnice kojima su im se vjerovnici, trgovci u dubrovačkim kolonijama diljem Balkana, obvezali na povrat kredita u ukupnom iznosu od preko 226000 dukata!), ${ }^{21}$ podatak o tome da je iznos štete od požara samo u trgovačkoj robi bio 10000 dukata, prestaje se doimati kao piščevo preuveličavanje.
Vijesti o požarima 16. stoljeća koje prenose dubrovački narativni izvori nisu međutim toliko motivirane razmjerima, pa ni štetama od pojedinih požara, koliko uz reakcije, rekli bismo "kolektivne psihoze" koje su, u sprezi s drugim, manje ili više uobičajenim događajima, neki od njih izazvali među stanovništvom. Tako je bilo is požarom kuće braće Babalio; kada se u zoru sljedećeg dana pred gradskom lukom pojavilo 12 mletačkih galija na povratku s Levanta, Dubrovčane je obuzela bojazan da je posrijedi više od puke koincidencije. Smjesta su pojačane straže i poduzete sve mjere pripravnosti, no galije su se, primivši od Dubrovčana uobičajene poklone, otisnule put zapada. ${ }^{22}$ Gotovo identičan slijed zbivanja zabilježen je sedam godina prije (1545.) kada je »od vrha do dna izgorjela jedna kuća kod crkve sv. Stjepana. U toj epizodi, opisanoj u ljetopisu anonimnog Dubrovčanina, ${ }^{23}$ doznajemo da požar nije bilo moguće ugasiti ni »uz pomoć svih naprava«, ali i o strahu koji je zavladao kada se sljedećeg dana pred gradom usidrila flota od 10 mletačkih galija. Sumnjalo se da je požar podmetnut kako bi se među stanovništvo unijela pomutnja i strahovalo da bi Mlečani pod okriljem noći mogli napasti grad, zauzeti ga i proglasiti se njegovim gospodarima. Zadržavši se nekoliko dana u cavtatskoj luci, mletačke su galije otplovile jer je takva, ustvrdio je ljetopisac, bila »Božja volja bez koje se ništa ne može učiniti«. Uistinu, te dvije vijesti o općim mobilizacijama stanovništva doimaju se gotovo kao prispodobe; sukus je "poruke" koju nam prenose njihovi pisci podsjećanje na krhkost premisa na kojima je počivala dubrovačka sloboda.

Svega tjedan dana poslije požara kuće braće Babalio, između grada i Lokruma (!) ukazala se flota od čak 19 mletačkih galija pod zapovjedništvom generalnog providura. ${ }^{24}$ Dubrovčani su i njima poslali »lijep poklon «, a uobičajena protokolarna razmjena pozdravnih artiljerijskih plotuna između topova na galijama i onih na gradskim tvrđavama značila je da Grad može odahnuti. ${ }^{25}$

O izgledu kuće braće Babalio poslije obnove moguće je govoriti samo hipotetski, jer se, ponovimo, sve spoznaje o tome zasnivaju tek na jednom dokumentu. Ako je svih devet naručenih prozora bilo namijenjeno istom pročelju - u tom slučaju zacijelo onom koje je gledalo na Crevljarsku ulicu (Od puča) - posrijedi je najvjerojatnije bilo "arhetipsko" simetrično pročelje s po tri otvora na svakoj etaži: ${ }^{26}$ manjim monoforama u zonama "sporednih" katova, te triforom između dviju monofora u zoni reprezentativnoga (drugog ili trećeg) kata. U odnosu na standarde dubrovačke stambene arhitekture toga doba, prozori kata na kojem se nalazila velika dvorana bili su iznimno velikih dimenzija. Visinom od oko 5 $\mathrm{m}$ monofore su, i bez skulptura visokih lakat i pol (oko 0,75 $\mathrm{m})$ koje su ih krunile, bile ravne monoforama na pročelju Sponze (ili biforama na drugom katu pročelja Dvora), a trifora okviru gotičke trifore čiji su tragovi sačuvani u zoni trećeg kata zapadnog pročelja Kuće Braichi-Isusović na Prijekom. Tomu treba pridodati i plastički efekt manjih balkona pred 


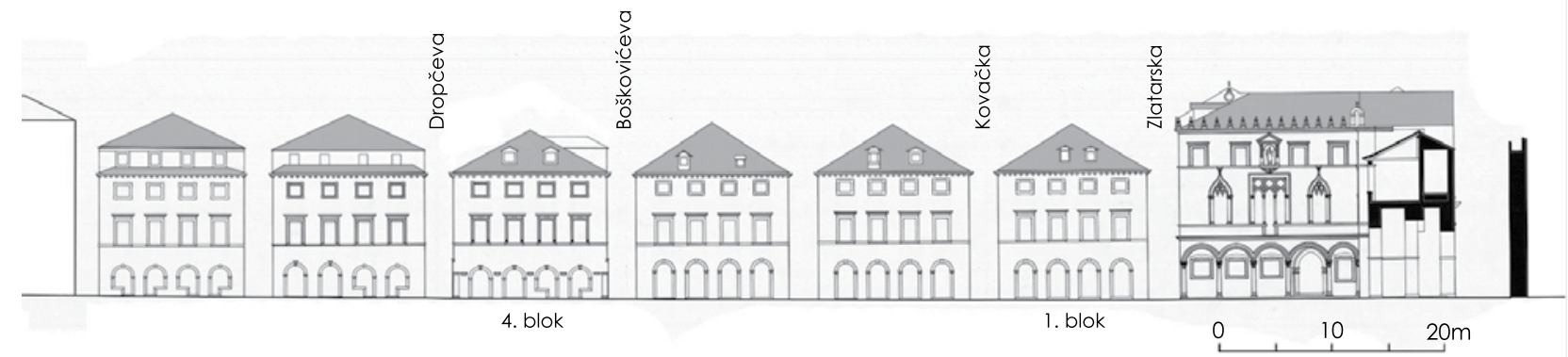

2. Građevine na istočnom dijelu sjevernog pročelja Place (arhitektonska snimka: Ivan Tenšek, Institut za povijest umjetnosti, 1970 ; grafička obrada: Davor Zuljan) / Row of buildings along the east part of Dubrovnik' main street Placa (architectural recording: Ivan Tenšek, Institute of art history, Zagreb, 1970.; computer drawing by Davor Zuljan)

monoforama i velikog balkona pred triforom, oslonjenog na snažne, klesanim reljefima ukrašene dvostruke konzole. ${ }^{27}$

Junije Mihov Babalio gradio je, kako se drži poslije 1567. godine, i ljetnikovac na Kantafigu, na ulazu u Gruški zaljev. ${ }^{28}$ To zdanje, danas zvano Ljetnikovac Bobaljević-Pucić, nosi dominantne tragove kasnijih stoljeća i na njegovim pročeljima nema arhitektonskih detalja koje bismo mogli povezati s onim što znamo o obnovi kuće u gradu; tek grb na obalnom pročelju pokazuje stanovite srodnosti sa skulpturalnim djelima koja je, postavivši ih u kontekst djelovanja Jakova Spinisa (u Dubrovniku, prema dokumentima, aktivnog do 1564.), sabrao Igor Fisković. ${ }^{29}$

Iz pripisa na margini ugovora iz 1552. razvidno je da je Jakov Spinis na tom poslu surađivao s klesarima Jeronimom Lombardijcem (čije se ime u dokumentima zapisuje i kao Jeronim Bartolomejev iz Messine) i Dubrovčaninom Ivanom Stjepanovim s kojima će se devet godina kasnije obvezati isporučiti klesane arhitektonske elemente za četvrti blok općinskih kuća na Placi. Posve se neuobičajenim, međutim, u ugovoru iz 1552. doima podatak da je cijeloj skupini klesara alat za rad u mljetskom kamenolomu dao sâm naručitelj Junije Mihov Babalio.

Ako je na osnovi iznijetih argumenata obnovu pročelja kuće braće Babalio dopušteno nazvati restauracijom, treba istaknuti da posrijedi najvjerojatnije nije bila faksimilska restauracija, nego nastojanje da se na pročelje aplicira standardno, "arhetipsko" rješenje. Vraćajući se na pitanje o motivima odabira dekorativnog repertoara na pročeljima (bez obzira na to bila riječ o "stilski" homogenim ili heterogenim cjelinama), treba ponoviti zaključak Nade Grujić: »kada su naručitelji pojedinih građevina članovi vlasteoskih porodica, isticanje izgledom kao da se odvija u okvirima provjerenih shema i oblika ${ }^{30}{ }^{30}$

\section{Četvrti blok općinskih kuća na Placi od 1559. do 1561. godine}

Sedam godina poslije kuće braće Babalio započinje obnova tzv. četvrte općinske kuće, točnije (od Sponze gledajući) četvrtog bloka općinskih kuća na Placi ${ }^{31}$ - između današnjih ulica Boškovićeve i Dropčeve (sl. 2) - izgorjelog krajem 1558. ili početkom 1559. godine. ${ }^{32}$ Nakon rasprave u Vijeću umoljenih, 8. veljače 1559. odlučeno je da se cijeli blok (scopulus) obnovi »s lukovima i svodovima« te da se pred njim podigne trijem po uzoru na trijem koji je načinio Jacopo Galliberti. ${ }^{33}$ Godine 1556., naime, na molbu toga trgovca iz Barlette, nedugo prije primljenog u red dubrovačkih građana, Vijeće umoljenih dodijelilo mu je u zakup na 25 godina cijeli prvi blok općinskih kuća do Sponze (između ulica Zlatarske i Kovačke), a Galliberti se zauzvrat obvezao da će, osim plaćanja fiksnih novčanih iznosa godišnjeg najma, o svom trošku građevinu popraviti i pred njom dati podići »kameni trijem sa stupovima i svodovima od jednog do drugog ugla bloka«, prema nacrtu predočenom Vijeću. ${ }^{34}$ Takva zamisao o svojevrsnom "javno-privatnom partnerstvu" - investiranju u popravak ili obnovu općinskih nekretnina koje se trebalo kompenzirati produljenom koncesijom - nije usamljen primjer. ${ }^{35}$

Sve do Gallibertova zahvata, o većim građevinskim zahvatima na općinskim kućama na sjevernoj strani Place nema sačuvanih vijesti. Svih šest blokova (iz imena uličice koja je vodila iza njihovih začelja saznajemo da su bili zvani Polačice ili Male polače), dočekalo je sredinu 16. stoljeća uglavnom u obliku u kojem su izgrađeni u drugoj polovini 14. stoljeća. ${ }^{36}$ Tijekom vremena, svakako prije sredine 15. stoljeća, kada nastaje najstariji sačuvani slikovni prikaz Grada (sl. 3), ${ }^{37}$ pred njihovim su prizemljima podignute crijepom pokrivene nadstrešnice čije se konstrukcije na kasnijim slikovnim prikazima doimaju kao provizorne, najvjerojatnije drvene.

O obnovi prvog ("Gallibertova") bloka svjedoči tek jedan pisani dokument - narudžba kamene građe za trijem od korčulanskog klesara Antuna Coste. ${ }^{38}$ Gallibertov podnesak Vijeću umoljenih bio je nedvojbeno "nadahnut" trijemom pred pročeljem Sponze - prema projektu Paskoja Miličevića podignutim potkraj drugog desetljeća 16 . stoljeća. ${ }^{39}$ Zamisao o tome da se nadstrešnice pred općinskim kućama zamijene monumentalnim kamenim trijemovima javila se najkasnije po dovršetku gradnje nove Sponze, pa se - izuzmemo li nje- 


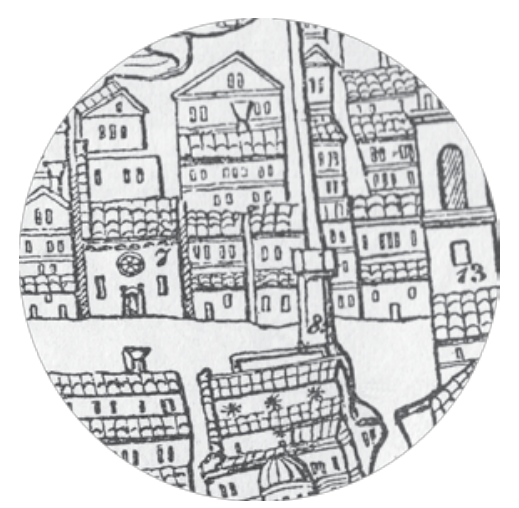

3. Općinske kuće zapadno od Sponze, detalj crteža prema reljefnom prikazu grada Dubrovnika u rukama sveca zaštitnika sredinom 15. stoljeća (prema M. Rešetaru; br. 7 - crkva Petilovrijenci, 8 - Orlandov stup/standarac; 13 - Gradski zvonik), Dubrovnik, crkva sv. Vlaha / Communal houses west of Sponza, a detail of the drawing after the relief representing the town of Dubrovnik in the hands of St Blaise, its patron saint, from the mid15th century (after M. Rešetar; № 7 - The church of Petilovrijenci; № 8 - The Orlando statue; № 13 - municipal belfry), Dubrovnik, Church of St Blaise

govu inicijativu i spremnost na investiranje - zasluge za trijem pred prvim blokom ne mogu, dakako, pripisati Gallibertiju. Da su okolnosti to dopustile, u konačnici bi jamačno svih šest blokova općinskih kuća između Sponze i Petilovrijenaca dobilo kamene trijemove. ${ }^{40}$ Oni su međutim, kako pokazuje detalj vedute u Društvu prijatelja dubrovačke starine (sl. 4), bili izvedeni samo pred prvim i četvrtim blokom.
Prvi ugovor o obnovi četvrtog bloka općinskih kuća registriran je 1. ožujka 1559. Od korčulanskih su klesara Luke Vasilića i Frane Karlića naručeni kameni trijem (pet stupova s lukovima) sa svodom, izvedbom identičan i cijenom jednak Gallibertovu trijemu, četiri lučno završena okvira vrata na koljeno (porte quattro e balconi con suoi archi de supra), tri manja pravokutna prozora »nad svodom « izrađena »na rimski način « (3 fenestre quali serano prime sopra il volto, lavorate alla romana), jedna vrata te četiri veća, također »rimska "prozora per desopra, za završni, drugi kat [Prilog - dokument II]. ${ }^{41}$ Svi su nabrojeni okviri, osim onih u prizemlju, trebali imati frizove i vijence (fregii et carnigie), a uz njih su naručena i četiri okvira vrata od neukrašenih kamenih greda (porte IIII con sue carnigie schiette), jamačno za ulazne otvore stambenih dijelova na bočnim pročeljima ili začelju bloka.

Uz četiri otvora vrata "na koljeno", ${ }^{42}$ na pročelju četvrtog bloka, u međuvremenu prezidanom, do danas su u zoni prizemlja sačuvani i tragovi trijema: udvojeni "dvovisinski" ugaoni pilastri s bazama i kapitelima, polustupovi na kojima su počivali bočni lukovi trijema te pet konzola na koje su bile oslonjene pete svodova trijema (sl. 5). Na njih su, kao na ostatke prijepotresne izgradnje, upozorili još Cvito Fisković i Lukša Beritić. ${ }^{43}$ Viši bočni pilastri pokazuju visinu završnog vijenca trijema, a niži pilastri i konzole na pročelju visinu kapitelne zone njegovih lukova. Treba primijetiti da je rješenje trijema na četvrtom bloku - s pilastrom koji prihvaća bočni luk - arhitektonski "čišćce" nego na Sponzi gdje je bočni luk trijema oslonjen na konzolu naknadno umetnutu u brid

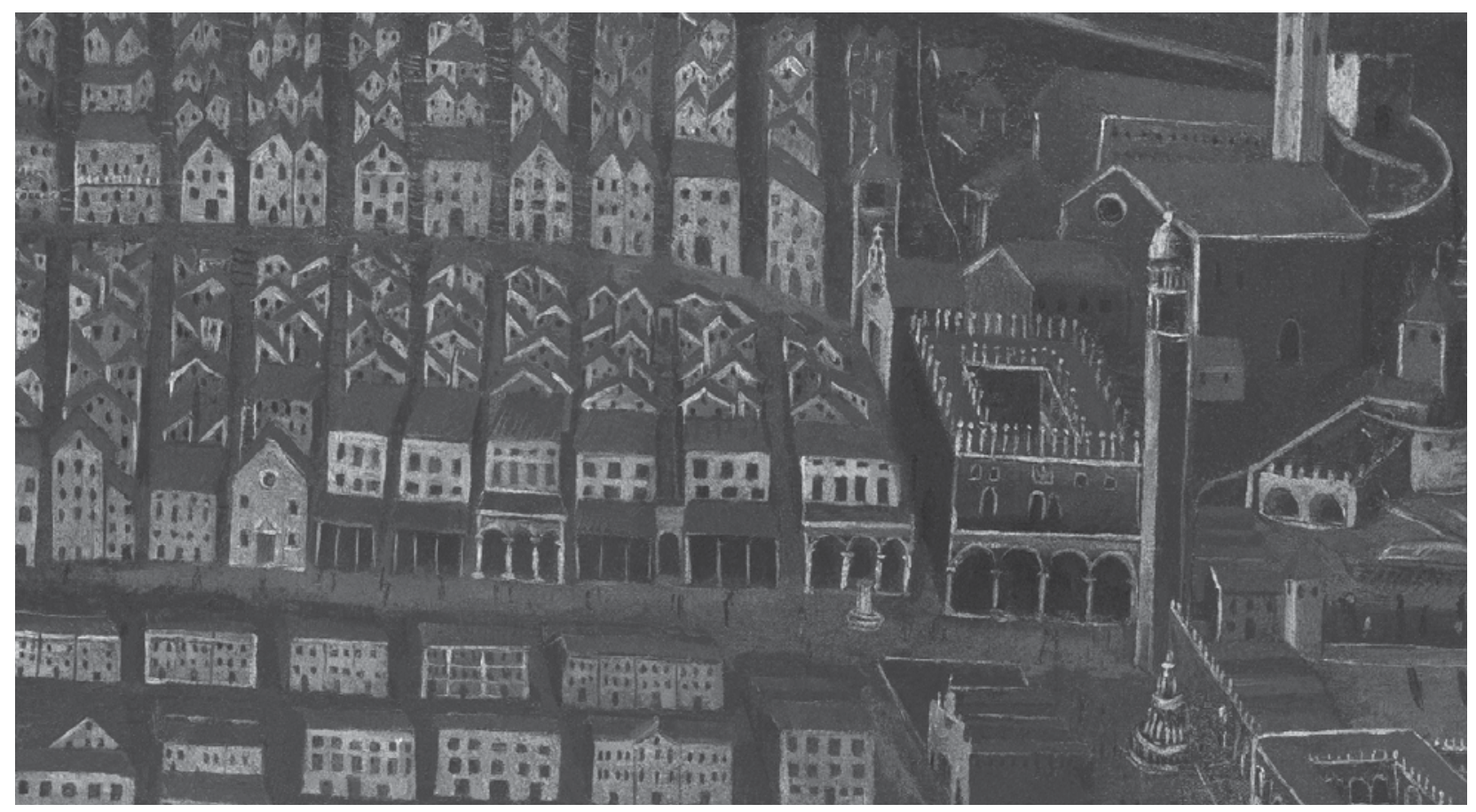

4. Građevine na istočnom dijelu sjevernog pročelja Place, između crkve Petilovrijenci i Sponze, na veduti Dubrovnika prije potresa 1667., Društvo prijatelja dubrovačke starine, Dubrovnik (foto: D. Vokić) / Row of buildings along the east part of Dubrovnik' main street Placa, veduta of Dubrovnik before the earthquake of 1667, Društvo prijatelja dubrovačke starine [Society of the Friends of Ancient and Historical Dubrovnik] 


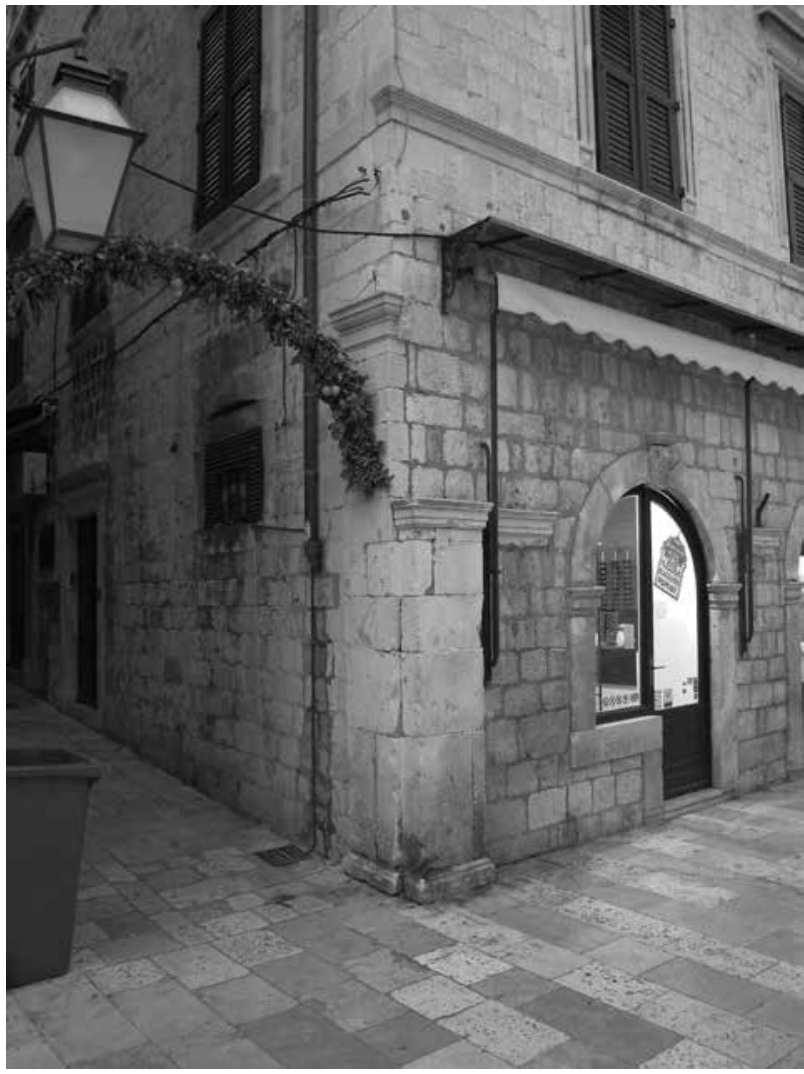

5. Ostaci konstrukcije trijema na pročelju četvrtog bloka općinskih kuća - udvojeni pilastri na jugozapadnom uglu i konzola svoda / Remains of the portico on the facade of the fourth block of communal houses - twin pilasters on southwest corner and the bracket of the vaulting

(starijega) pročelnog zida. Tri od spomenutih pet konzola svodova trijema četvrtog bloka postavljene su u osima zidnih polja između četiriju vrata dućana, a dvije "vanjske” u osima polja između vrata i pilastara uz bridove pročelja. Svod čija je konstrukcija, s obzirom na broj stupova, trebala imati četiri cijela kvadratna svodna polja i, uz ugaone pilastre, još tri konzole, na pročelju je, dakle, umjesto pet imao ukupno sedam oslonaca, a njegova tlocrtna projekcija nije bila posve pravilna. To je proizašlo iz nemogućnosti da se geometrija svoda u cijelosti uskladi s rasporedom otvora prizemlja. Vrata dućana nisu naime razmještena ravnomjerno po širini pročelja, jer bi to (zbog debljine bočnih zidova građevine) onemogućilo da prostor prizemlja bude podijeljen na četiri jednaka dijela, pregradnim zidovima koji su nosili i svodove u unutrašnjosti.

Drugi dokument o obnovi četvrtog bloka jest ugovor s Jakovom de Spinisom i njegovim drugovima Jeronimom Bartolomejevim iz Messine i Dubrovčaninom Ivanom Stjepanovim, registriran 2. siječnja 1561. godine [Prilog dokument III] . Od nekoliko skupina klesarskih proizvoda koji su tada naručeni za gornji dio (katove) građevine, pozornost u prvom redu privlače četiri okvira prozora alla romana za koje se traži da dimenzijama i obradom budu egzaktne replike takvih prozora na kući Junija i Marina, sinova Benedikta Restija.

Vijesti u dva ugovora sklopljena s dvije skupine klesara donekle su proturječne; budući da se oba dokumenta neprijeporno odnose na četvrti blok, ${ }^{44}$ valja postaviti pitanje zašto su dvaput u nepune dvije godine naručeni prozori za njegovo glavno pročelje.

Prema ugovoru s korčulanskim klesarima, na prvom su kat predviđeni okviri dimenzija svijetlih otvora $84 \times 134 \mathrm{~cm}$, a za drugu, završnu etažu $125 \times 175 \mathrm{~cm} .{ }^{45}$ I okviri prozora koji se naručuju od Spinisa 1561. godine namijenjeni su zoni prvog kata. Štoviše, prozori prvog kata na današnjem pročelju (sl. 6) upravo su, držimo, četiri »rimska " prozora naručena od Spinisa; mezze colonne d’attorno njihove su središnje, plastički dominantne profilacije oblog štapa (koje s doprozornika kontinuiraju na natprozornike), a cartoni stilizirane kartuše na frizovima.

Usporedimo li dimenzije prozora naručenih za prvi kat u prvom ugovoru (1559.) s današnjim, izvedenim stanjem (svijetli otvori 112x200 cm), možemo zaključiti da je prvotni projekt obnove bloka predviđao zadržavanje starije vertikalne podjele, kako u unutrašnjosti tako i na pročelju bloka (s niskim prvim i visokim drugim katom), ali i da je tijekom radova promijenjen odnos visina triju etaža. Povod za podizanje razina podova prvog i drugog kata najvjerojatnije je bila ugradnja svodova nad dućanima u prizemlju. Budući da je visina građevine bila zadana - završni vijenci pročelja šest blokova do Sponze na istoj su visini kao potprozorni vijenac njezina drugog kata - povisivanje prvog kata moglo je biti kompenzirano samo snižavanjem završne, druge etaže. Isto se dogodilo i na pročelju: konstrukcija trijema sa svodovima pokrila je veći dio zone starijega, niskog prvog kata, pa je ulogu reprezentativne etaže dobila zona novoga prvog kata.

Zona drugog kata četvrtog bloka rastvorena je manjim prozorima u obliku položenog pravokutnika (svijetli otvori $112 \times 93 \mathrm{~cm}$ ). Prozore toga tipa - zvane i »mezaninskima« - i danas imaju završni katovi većine kuća na Placi, a na trokatnicama na njezinu južnom pročelju i zone niskih prvih katova. Oblikom i kompozicijskom shemom svojih okvira - s karakterističnim ugaonim »ušima« - prozori drugog kata četvrtog bloka u vremenu njegove obnove (1559.-1562.) nisu u Dubrovniku bez presedana; nalazimo ih na više reprezentativnih dubrovačkih kuća 16. stoljeća, redovito, doduše, u funkciji otvora "tehničkih prostorija", primjerice u zoni prizemlja sjevernog pročelja Kuće Bona na Bunićevoj poljani koju je Nada Grujić interpretirala kao jedno od antologijskih ostvarenja renesansne stambene arhitekture $\mathrm{u}$ Gradu i datirala u drugu polovinu 16. stoljeća. ${ }^{46}$ Prozori drugog kata četvrtog bloka u ugovoru sa Spinisom i drugovima se međutim ne spominju, ali u prilog zaključku da su ugrađeni kada i od Spinisa naručeni prozori prvog kata, govori ponajprije odgovarajući detalj na veduti u Društvu prijatelja dubrovačke starine: osim kamenim trijemovima (umjesto s pet, prikazanim $s$ 


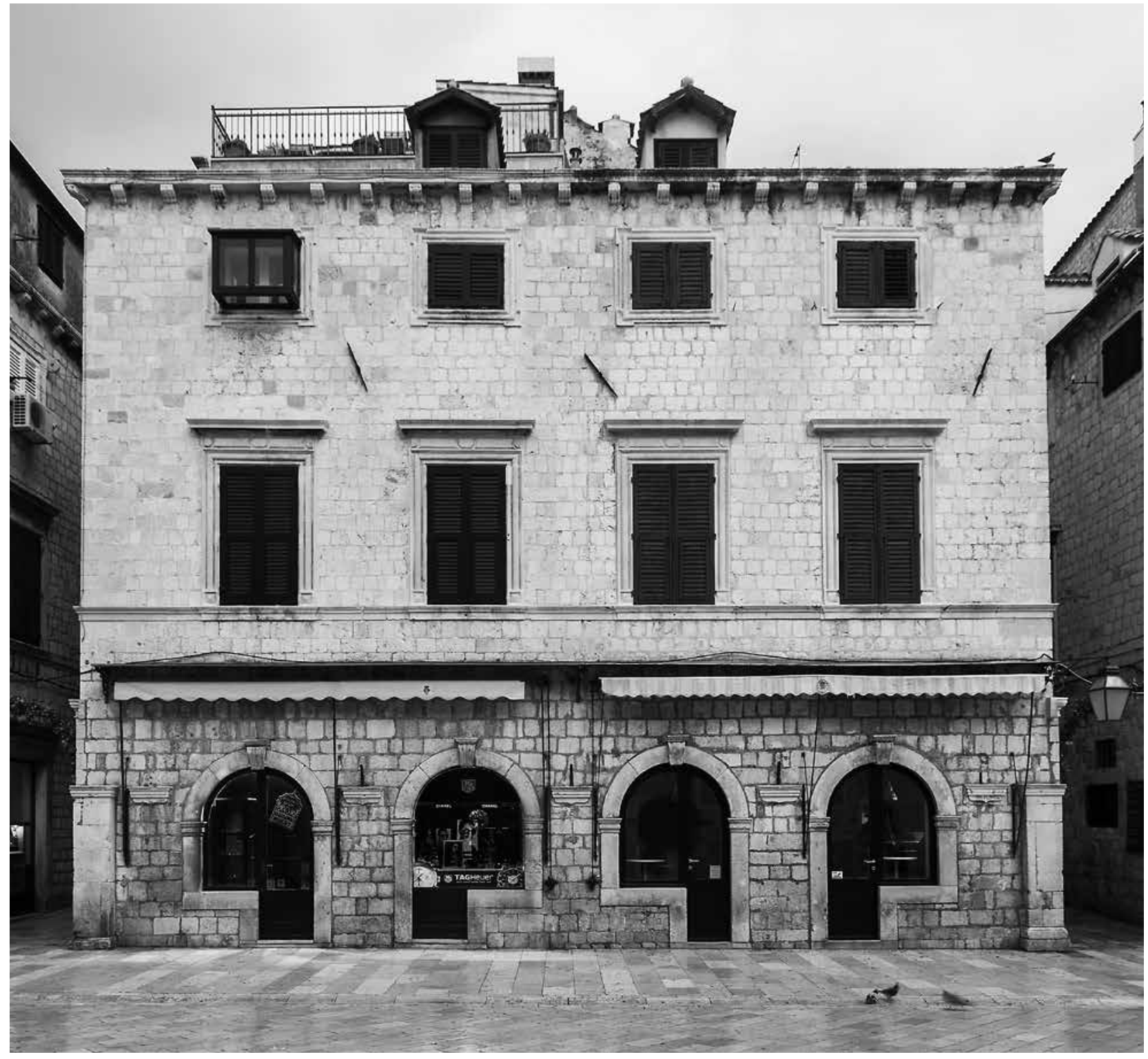

6. Pročelje četvrtog bloka općinskih kuća (foto: P. Mofardin) / The facade of the fourth block of communal houses

četiri stupa!), prvi i četvrti blok razlikuju se od ostalih upravo, unatoč stupnju stilizacije prikaza neupitnim, formatima, odnosno proporcijama prozora gornjih etaža.

Smije li se ustvrditi da je "autor" prozora drugog kata bio također Jakov Spinis? Čak i kada bismo raspolagali nedvosmislenom arhivskom vijesti da ih se obvezao isporučiti, ne bi bilo moguće izričito ustvrditi da ih je sam i klesao ili za njih načinio nacrte, štoviše "njegovoj ruci" ne mogu se kategorički pripisati ni okviri prozora prvog kata. O izravnim predlošcima potonjih, prozorima na kući braće Restija, također ne znamo ništa. Ipak, imajući u vidu stanje ponude na lokalnom tržištu kamenoklesarskih usluga pedesetih godina 16 . stoljeća - ali i dokumentirane primjere petnaestostoljetne prakse da se u Dubrovniku od klesara nerijetko naručuju replike prema uradcima koje su ti isti klesari bili ranije isporučili - Spinisu je sa stanovitom dozom opreza moguće pripisati ne samo design, tj. arhitektonsko rješenje okvira prozora na prvom katu četvrtog bloka, nego možda i onih na kući braće Restija. ${ }^{47} \mathrm{U}$ prilog zaključku da su okviri prozora prvog i drugog kata na pročelju četvrtog bloka zamišljeni i ugrađeni istodobno, u zahvatu obnove početkom šezdesetih godina 16. stoljeća, po našem sudu, unatoč razlikama koje pokazuju na prvi pogled, govore i evidentno komplementarne sheme sustava njihovih profilacija, proizašle iz istoga plastičkog poimanja arhitektonskog ukrasa. U razmatranju o "autorstvu" četvrtog bloka, po svemu sudeći, treba razlučiti tri segmenta - projekt trijema (koji je bio programiran ranije), potom projekt pročelja i, ne zaboravimo, projekt interijera. Osim Spinisa čiji udio na pročelju nije upitan, zasluge za definiranje arhitektonskog 


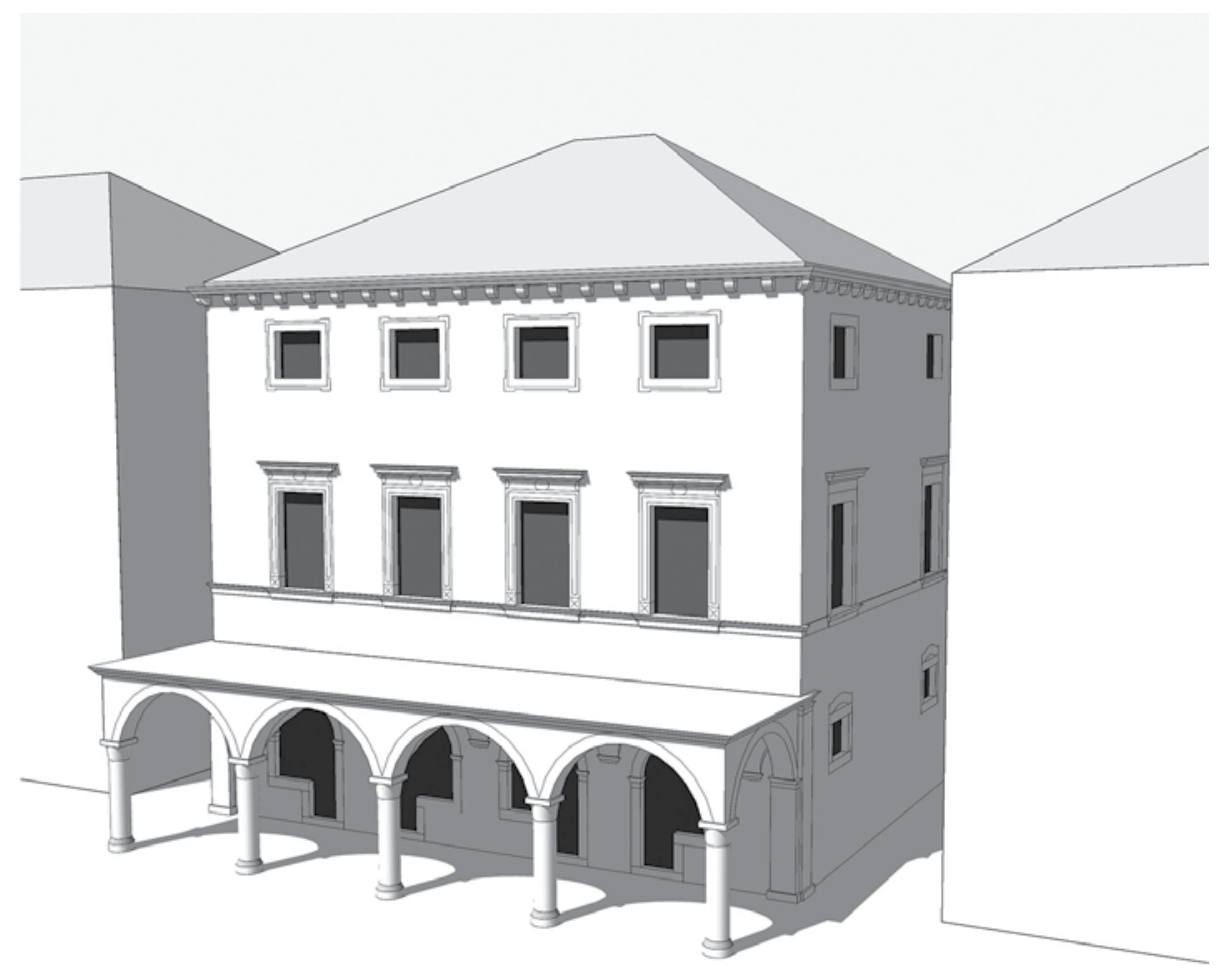

7. Četvrti blok općinskih kuća poslije obnove 1559.-1562. (arhitektonska snimka: Institut za povijest umjetnosti; 3D grafika: Davor Zuljan) / The fourth block of communal houses after the renewal 1559-1562 (architectural recording: Institute of art history, Zagreb; 3D graphics by Davor Zuljan)

programa obnove jamačno je imao i Kristofor Franov Cabo$\mathrm{ga},{ }^{48}$ jedan od trojice izabranih oficijala super fabrica duarum domuum communis combustarum in via lata, koji je sklopio oba ugovora s klesarima - 1559. i 1561. godine. Četvrti blok dovršen je, točnije useljen, u veljači 1563. godine. ${ }^{49}$

Obnova četvrtog bloka općinskih kuća započeta je dakle, po svemu sudeći, kao restauracija, da bi potom bila nastavljena i dovršena kao rekonstrukcija (sl. 7). Za promjenu arhitektonskog programa, još presudnije od prigrađivanja trijema, bilo je, kao što je istaknuto, interpoliranje svodova u prizemlju. To nije učinjeno iz statičkih, nego iz sigurnosnih razloga; gradnja svodova (umjesto drvenih stropova) nad prizemljima ili prvim katovima jedna je od uobičajenih, standardnih protupožarnih mjera, u privatnim i općinskim kućama. ${ }^{50}$

Spinisovo je pročelje četvrtog bloka, $\mathrm{k}$ tome, postalo svojevrsnim prototipom za kuće građene na Placi u 17. stoljeću, kako prije, tako i poslije potresa. Potvrde li buduća istraživanja tu hipotezu, pokazat će se da karakteristična shema pročelja većine građevina duž sjevernog oboda glavne gradske komunikacije nije nastala u vremenu poslijepotresne (barokne) obnove, nego je zasnovana upravo na rješenju pročelja četvrtog bloka iz 1561. godine.

$\mathrm{S}$ obzirom na mjesto obnovljenoga četvrtog bloka $\mathrm{u}$ općoj slici stambene izgradnje u Dubrovniku 16. stoljeća, treba podsjetiti da su općinske kuće, slijedimo li uobičajene podjele, negdje između »stambene« $i$ »javne« arhitekture, one su štoviše i javne i stambene građevine. Premda jasno diferencirane (javnim) vlasništvom i vrstom korištenja (iznajmljivanjem na dražbama svakih pet godina), blokovi općinskih kuća na razini arhitektonskog vokabulara ne pokazuju nikakva specifična obilježja. Stoga i nije iznenađujuće što se u ugovoru sa Spinisom traži da prozori prvog kata budu replike prozora koji su se nalazili na jednoj privatnoj kući, braće Restija, sotto la sala, tj. ispod zone kata na kojem se nalazila velika dvorana. Drugim riječima, fenestre romane "običnog" kata vlasteoske kuće svojim su oblikom, dimenzijama i shemom ukrasa odabrane kao najprikladniji predložak za prozore "glavnog" kata bloka općinskih kuća. Unatoč svemu, za obnovljeni se četvrti blok općinskih kuća ne može ustvrditi da mu je oblikovanje bilo neambiciozno ili "minimalističko", ograničeno htijenjem da se udovolji tek najnužnijim funkcijama. Zanemarimo li monumentalni trijem, budući da je podignut u sklopu općenitije ideje urbanističkog usavršavanja prostora na obodu glavne gradske komunikacije, uz reprezentativne okvire pročelja treba naime upozoriti i na druge klesane elemente opreme zdanja. Od Spinisa je 1561. zatražen i vijenac koji će "poslužiti kao pojas kuće" (corisa che servira per la cinta della casa); zacijelo potprozorni vijenac otvora prvog kata, jer njegova duljina - 56 lakata, tj. oko $28 \mathrm{~m}$ - odgovara zbroju duljina glavnog i dvaju bočnih pročelja. ${ }^{51}$ Naručena tri kamena stubišta koja su iz prizemlja vodila prema katovima, ${ }^{52}$ četiri umivaonika, dva kamina oblikovana "na francuski način» 


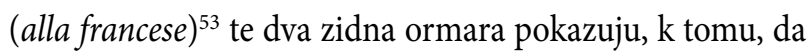
ni opremljenošću interijera općinske kuće, unatoč svojim zadanim, uistinu minijaturnim dimenzijama, nisu zaostajale za privatnim zdanjima svoga vremena.

S obzirom na renesansni vokabular oblika na pročelju, treba istaknuti i nekoliko termina u ugovorima koji svakako pripadaju renesansnom arhitektonskom nazivlju: za razliku od prozora s vijencima (carnigie) traženih 1559. godine, od Spinisa se 1561. naručuju prozori con suoi frontispicii što daje naslutiti da su prozori prvog kata (danas sa završnim vijencima), izvorno trebali biti zaključeni zabatima. Pozornost privlači i termin festa (festa quale sera posta dentro via sopra le porte e balconi) u ugovoru iz 1559., no posrijedi je naziv za reljefno (motivom volute) ukrašene zaglavne kamenove lučno završenih vrata dućana u prizemlju.

Analizirajući različite aspekte fenomena suživota dvaju stilova u stambenoj i javnoj arhitekturi Dubrovnika, fenomena koji je jednom zgodom okarakterizirala kao »dijalog između gotike i renesanse $\lll,{ }^{54} \mathrm{Nada}$ Grujić je u raspravu uvela sintagmu »društvena estetika.$^{55}$ Doista, riječ je neprijeporno o društvenom ukusu; možda bismo - podsjećajući na dijametralno suprotnu retoriku koja je pročelje kuće Junija Mihova Babalija dijelila od pročelja kuće bogatog pučanina Tome Stjepovića Skočibuhe, također građene u šestom desetljeću 16. stoljeća - dodali: staleški ukus. Negdje u sredini između ta dva zdanja bio je četvrti blok općinskih kuća polačica koju bi jamačno, kao "kuću savršene trgovine", 56 bio pohvalio i sâm Benedikt Kotrulj.

\section{Prilog - dokumenti}

I.

14. kolovoza 1552. Magistar Jakov de Spinis iz Orléansa, Francuz, klesar, obvezuje se Juniju Mihovu Babaliju isporučiti klesane elemente za pročelje kuće u seksteriju sv. Vlaha.

[Die XIIII augusti 1552] Magister Iacobus de Spinis de Orliens Gallus lapicida ad interogationem ser Iunii Mich. de Babalio ibidem presentis ac pro se suisque fratribus stipulantis, sponte et omni meliori modo promisit et convenit dare et consignare eidem ser Iunio hinc ad festum Pentecostis proxime venturum infrascripta omnia et singula laboreria de scarpello, pactis, conditionibus et obligationibus in hunc qui sequitur modum, videlicet:

In primis promisit dare et consignare novem balchiones seu fenestras de petra de scarpello de meliori ac pulchriori petrarie insule Melite de his modellis, videlicet: sex de modello fenestrarum faciei palatii magnifici domini rectoris civitatis Rhagusii, unam de modello maioris et principalis fenestre domus ser Iunii Mich. de Bona et duas de modello fenestrarum que sunt a latere dicte maioris fenestre domus dicti ser Iunii. Et quod omnes et singule dicte fenestre seu balchiones erunt in quadro tante grossitudinis quod implebunt totam grossitudinem muri domus eiusdem ser Iunii et fratrum, posite in sexterio sancti Blasii. Et quod dicti sex balchiones qui debent esse secundum modellum balchionum palatii civitatis Rhagusii erunt eiusdem altitudinis in facie qua sunt dicti balchiones prefati palatii. Ceteri vero tres qui debent esse secundum modellum fenestrarum domus dicti ser Iunii, erunt altitudinis brachiorum decem, latitudinis vero, videlicet, maior cum duabus columnis brachiorum sex et cetere due latitudinis eius qua sunt dicti duo balchiones domus prefati ser Iunii in facie.

Item promisit dare et consignare quatuor modionos principales cum suis quatuor modionibus bastardis de scarpello de dicta petra, pro eis ponendis et subponendis sub dicta fenestra maiori, et quod erunt quatuor maiores longitudinis brachiorum sex et grossitudinis brachii unius quadrature pro quolibet. Ceteri vero quatuor minores quod erunt longitudinis et grossitudinis proportionate suis prefatis maioribus modionibus. Et quod erunt omnes modiones prefati laborati et intagliati laborerio et intagliatura convenienti ac condecenti laborerio et intagliatura dicte fenestre maioris.

Item promisit dare et consignare duas planas seu tabulas de scarpello de dicta petra, quamlibet de una petia ac grossitudinis unciarum quatuor, et quod erit quelibet laborata ac sovaggiata laborerio ac sovaggiatura convenienti ad laudum praticorum virorum et quod erunt tante latitudinis quante erunt fenestre et longitudinis tante ut implebunt sub parestato fenestrarum totam grossitudinem muri et extra murum exibunt per faciem per brachium unum de pluri, et erunt prefate due tabule seu plane pro eis ponendis sub duabus illis fenestris que erunt a latere fenestre maioris.

Item promisit dare et consignare duas statuas de scarpello de dicta petra, altitudinis quamlibet brachii unius cum dimidio, pro eis ponendis supra circumferentiam dictarum duarum fenestrarum, et quod erunt illarum figurarum que fuerint electe per ipsum ser Iunium, ac adeo bene et diligenter laborate quod erunt proportionate in omnibus eius partibus et lineis, ac laudum pratici magistri in arte.

Que quidem omnia et singula laboreria de scarpello idem magister Iacobus promisit et convenit conducere infra tempus ut supra specificatum ac ponere in locis domus dicti ser Iunii in quibus stare perpetuo debent et hoc ad omnes expensas suas exceptuato magisterio muratorum ac exceptuatis argatis et cordis. Ser Iunius vero predictus super se et omnibus suis bonis pro se et fratribus suis sponte promisit et convenit dare et solvere dicto magistro Iacobo presenti et stipulanti pro omnibus et singulis premissis laboreriis ac specificatis rebus ducatos auri centum triginta, solvendos alla giornata prout laboreria fient, et hoc in pace et sine lite, omni contradictione cessante. Renuntiando.

Die XXVII augusti 1552. Iacobus de Spinis contrascriptus lapicida sponte contentus et confessus fuit habuisse et recepisse a ser Iunio contrascripto scutos septem ad computum conventionis contrascripte et Hieronimus Lombardus confessus fuit 
recepisse a dicto ser Iunio scutos duos, Ioannes Stephani scutos duos, Lucas Iliich scutos duos et Marinus Givaglievich scutos duos, quos scutos octo dictus ser Iunius solvit predictis quatuor de voluntate et consensu Iacobi suprascripti et pro eius computo pro parte conventionis contrascripte eo quia cum ipso vadarunt Meledam ad laborandum, et de pluri omnes suprascripti insolidum et ad melius tenendum se obligarunt pro scutis decem pro sicurtate feramentorum eis datorum per dictum ser Iunium adeo si feramenta eidem ser Iunio non restituerunt quod teneantur ei solvere dictos scutos decem. Renuntiando.

(DAD, ser. 25. Diversa Cancellariae, sv. 137, ff. 64v-65v)

(Dokument je većim dijelom objavljen u: CVITO FISKOVIĆ, Artistes français en Dalmatie, Annales de l'Institut français de Zagreb, 10-11 (1946.-1947.), 18, a, bez naknadnog upisa na margini, u prijepisu Zdravka Šundrice, u: NADA GRUJIĆ, Kuća u Gradu. Studije o dubrovačkoj stambenoj arhitekturi 15. i 16. stoljeća, Matica hrvatska, Ogranak Dubrovnik, Dubrovnik, 2013., 399-400).

II.

1. ožujka 1559. Magistri Luka Vasilić (Vaseljić) i Frane Karlić, klesari iz Korčule, obvezuju se Kristoforu Franovu Cabogi isporučiti klesane elemente trijema, prozora i vrata za izgorjelu općinsku kuću na Placi.

Die primo martii 1559. De voluntate et consensu ser Christofori Fran. de Caboga et sociorum officialium super fabrica duarum domuum communis combustarum in via lata et Lucae Vaseglich ac Francisci Carlich lapicidarum de Corzula, infrascripta conventio hic registrata fuit que talis est:

Magistri Lucas Vasseglich et Franciscus Carlich de Corzula lapicide sponte cum ser Christoforo Fran. de Cabogha et sociis officialibus fabricae duarum domuum combustarum obligantes se in solidum et ad melius tenendum obligaverunt pro laboreriis infrascriptis se facturi sopra tam infra declarabilem in chirografo a dictis partibus presentato cuius forma talis erat.

Li magistri infrascriti prometteno dar e consegnar cinque collonne con sua pedata e capitelli e con archi fra dicte collonne lavorati et similmente con archi de dentro et con suo corso de supra gli archi et con la lista de supra, con appresso porte quattro e balconi con suoi archi de supra, e la lista sfagiata supra gli archi sudetti in modo e forma come sta nel scacho di Iacobo Galliberto, e tutti scarpelli siano lavorati come da dicto Iacobo, e questo per pretio de ducati novanta cinque: val <duc. 95>.

Item 3 fenestre quali serano prime sopra il volto, lavorate alla romana de longheza overo altezza braza $2 \frac{2}{3}$ e di largheza in luce brazza 12/3.

Item una porta sfagiata di altezza brazza 33/4 e larga in luce brazza 2.

Item quattro fenestre lavorate alla romana per desupra de altezza brazza 31/2 e di largezza brazza 21/2.

E tutte le dette VII fenestre con suoi fregii e carnigie e la detta porta habbi il fregio et la carnisia, quale fenestre e porta debbeno esser in fazza onzie 5 , per precio e mercato de grossetti $V$ per brazzo, fuor del fregio, et il fregio quanto lo sera stimato.
Item porte IIII con sue carnigie schiette di altezza brazza 4 e di largheza in luce brazza 2 e onzie 1 , per pretio e mercato di grossetti quattro il brazzo. Li quali siano in faccia onzie 51/2, del el qual scarpello siano tenuti ad condurre per tutto augusto proxime futuro e non portano altri se possano comprare dalli altri a spese et interesse suo et lese detti per parte et a buono conto ducati trenta sei.

Item dichiararono che quando si trovera che ser Iacobo Galliberto habbi pagato manco di quello e stato desopra dichiarito, che detti officiali habbeno pagare tanto quanto lui. Et di piu serano li prefati officiali tenuti di pagare alli predicti maestri la festa quale sera posta dentro via sopra le porte e balconi.

Et statim venerabilis presbiter ser Franciscus Michaelis se pro dictis lapicidis statim constituit fideiiussorem tam pro pecuniis praedictis quam pro rebus aliis omnibus contentis in praesenti chirografo. Renuntiando. Iudex ser Savinus Io. de Goze et Nicolaus Primi testis.

Die 18 iulii 1559. [f. 147v, in margine] Franciscus Carlich contrascriptus sponte confessus fuit se habuisse et recepisse a ser Christoforo Francesci de Caboga et sociis officialibus contrascriptos ducatos auri decem ad computum contrascriptorum laboreriorum pro quibus de ratione promittit pro Luca Vasilich socio suo. Renuntiando.

(DAD, ser. 36.b. Debita Notariae pro Comuni, sv. 1, ff. 147v-148r) (Dokument spominje CVITO FISKOVIĆ, Naši graditelji i kipari XV. i XVI. stoljeća u Dubrovniku, Matica hrvatska, Zagreb, 1947., 60)

III.

2. siječnja 1561. Magistar Jakov Spinis i njegovi drugovi Jeronim Bartolomejev iz Messine i Ivan Stjepan Dubrovčanin obvezuju se isporučiti klesanu arhitektonsku opremu za građevinu koja se podiže na Placi na mjestu kuća s dućanima izgorjelih u požaru.

Ser Christophorus Francisci de Caboga tanquam unus ex dominis provisoribus fabricae novae comunis quae fit loco domorum et apothecarum igne concrematorum ex una et magister Iacobus de Spino Gallus lapicida et socii eius Hieronymus Bartholomei Messinensis habitator Ragusii et Ioannes Stephani Raguseus et lapicida omnes tres in solidum et ad melius tenendum ex parte altera exhibuerunt concorditer et presentaverunt mihi presentis catastici publico et iurato cancellario infrascriptum aricordium in uno folio papiri scriptum eisdem sociis a dicto ser Christophoro datum et exhibitum et per ipsos socios acceptatum. Que partes sponte sibi invicem et vicisim, videlicet una pars alteri et altera alteri, dictum ricordium et contenta in eo observare promiserunt et convenerunt sub obligatione et hyppotheca omnium bonorum suorum et presertim dicti socii in solidum consenserunt se in causa ommissionis aut conventionis que ex parte eorum occurerent posse capi, carcerari et mulctari usque ad integram observationem contentorum in ipso aricordio et si et quatenus in termino non dabunt et consignabunt laboreria, scilicet 
lapides de quibus in ipso aricordio, quod scripti provisores ad ipsorum sociorum expensas et damna ab aliis accipere possint et valeant omni iuris et facti exceptione remotta et cessante.

Et cuius aricordii tenor est qui sequitur, videlicet: Ricordo facciamo a voi maistro Hieronimo Messinese et compagni noi proveditori della casa si fabrica in Piazza di Ragusa. Voi andarete alla volta di Curzola gionto che sarete attenderete prima a fare fenestre quattro alla romana con suoi frontispicii di sopra, con meze collone d'attorno, con li cartoni e con tutti li altri lavori e scarpelli si come sono in le finestre sotto la sala della casa di ser Giugno et ser Marino Benedetto di Resti et di quella medema altezza et larghezza et ancho di quella grossezza in faccia et in coda come le dette di quelli di Resti per precio et mercato di ducati trentadue cio e a ducati otto per finestra.

Item ne poi farete braza 56 di corisa che servira per la cinta della casa di grossezza onze $4 \frac{1}{2}$ com lo suo gradetto et altri ordinarii lavori nella qual brazattura sono computati li soiari dabasso per li quali vi promettemo pagar quanto sarano stimati da boni maestri.

Item scalini 30, cio e scalini 24 di braza $2^{1 / 1} 4$ l'uno et scalini numero 6 di braza 21/2 l'uno con suoi bastoni a ragion di grossi nove l'uno, et li detti scalini sei serano con la testa alla sinistra.

Item lavatori 4 di braza 2 di largezza l'uno et di altezza braza 2 onze 10, che siano sfaggiati con suo frixio et cornixa per li quali vi si dara tanto quanto saranno stimati.

Item due caminate lavorate alla francese in luce braza 2, onze 2 in quadro et quelle vi pagaremo quello saranno stimati.

Item dui armarii lavorati con suo friggi et cornice d'altezza braza 31/2 l'uno et di altezza braza dui in luce et questi vi se pagaranno quello sarano stimati.

Et a bon conto per sudetti scarpelli v' habbiamo dati scudi quindeci.

Et detti scarpelli et lavori haverli condotti qui a Ragusa per tutto febraro prossimo futuro.

(DAD, ser. 25. Diversa Cancellariae, sv. 146, ff. 233r-234v) (Objavio: CVITO FISKOVIĆ, Les artistes français en Dalmatie du XIV ${ }^{e}$ au XVII siècle, Annales de l'Institut français de Zagreb, n. s. 14-17 (1964.-1965.), 37)

\section{BILJEŠKE}

1 LUKŠA BERITIĆ, Urbanistički razvitak Dubrovnika, Zavod za arhitekturu u urbanizam Instituta za likovne umjetnosti JAZU, Zagreb, 1958., 15; Statut grada Dubrovnika sastavljen godine 1272., (prir.) Ante Šoljić, Zdravko Šundrica i Ivo Veselić; uvodnu studiju napisala Nella Lonza, Državni arhiv u Dubrovniku, Dubrovnik, 2002., knj. VIII, gl. 57, 460-467.

2 Annales Ragusini anonymi, Annales Ragusini anonymi item Nicolai de Ragnina, (prir.) Speratus Nodilo, [Monumenta spectantia historiam Slavorum meridionalium 14, Scriptores 1], Academia scientiarum et artium Slavorum meridionalium, Zagrabiae, 1883., 41.

3 LUKŠA BERITIĆ, Ubikacija nestalih građevinskih spomenika u Dubrovniku, Prilozi povijesti umjetnosti u Dalmaciji, 10 (1956.), 17; Statut grada Dubrovnika (bilj. 1), knj. VIII, gl. 60, 470-473.

4 Usp. poglavlje Između dva požara - općinske nekretnine i sustav najmova u 14. stoljeću uvodne studije u ediciji Knjige nekretnina dubrovačke općine (13-18. st)/Libri domorum et terrenorum communis Ragusii de- liberatis ad affictum (saecc. XIII-XVIII), I-II, (prir.) Irena Benyovsky Latin, Danko Zelić, Zavod za povijesne znanosti HAZU u Dubrovniku, Zagreb-Dubrovnik, 2007., I, 33-48.

5 O dubrovačkim postignućima u borbi protiv požara od 13. do 15. stoljeća v. BARIŠA KREKIĆ, Dubrovnik's Struggle against Fires (13th - 15th centuries), Dubrovnik: A Mediterranean Urban Society, Variorum, London, 1997., 1-24.

6 NADA GRUJIĆ, Onofrio di Giordano della Cava i Knežev dvor u Dubrovniku, Renesansa i renesanse u umjetnosti Hrvatske. Zbornik radova sa znanstvenih skupova "Dani Cvita Fiskovića» održanih 2003. i 2004. godine [Zbornik Danā Cvita Fiskovića, sv. 2.], (ur.) Predrag Marković, Jasenka Gudelj, Institut za povijest umjetnosti u Zagrebu; Odsjek za povijest umjetnosti Filozofskog fakulteta, Zagreb, 2008., 9-50.

7 CVITO FISKOVIĆ, Naši graditelji i kipari XV. i XVI. stoljeća u Dubrovniku, Matica hrvatska, Zagreb, 1947., 24, 60; v. Prilog, dokumenti I-III. 8 Spinisovo je djelovanje u Dubrovniku rasvijetlio CVITO FISKOVIĆ, Artistes français en Dalmatie, Annales de l'Institut français de Zagreb, 10-11 (1946.-1947.), 16-20; CVITO FISKOVIĆ, Les artistes français en Dalmatie du XIV au XVII siècle, Annales de l'Institut français de Zagreb, n. s. 14-17 (1964.-1965.), 29-32, donoseći i sve inačice zapisivanja imena francuskog klesara (Giacomo ili Jacopo Francese sculptore, Jacobus de Spino Gallus lapicida, Jacobus Ghespinus, magister Jacobus de Spina Gallus de Orliens, magister Jacobus de Spinis de Orliens), v. i CVITO FISKOVIĆ, Francuski gotički i renesansni majstori u Dalmaciji, Mogućnosti, 14/1-2 (1967.), 150-151.

Recentno je novim atributivnim prijedlozima "katalog" Spinisova dubrovačkog opusa zaokružio IGOR FISKOVIĆ, Maniristički vrt Crijevića u Dubrovniku, Anali Zavoda za povijesne znanosti HAZU u Dubrovniku, 43 (2003.), 175-210; IGOR FISKOVIĆ, Preobrazbe rječnika kamene ornamentike u Dubrovniku 16. stoljeća, Renesansa i renesanse u umjetnosti Hrvatske. Zbornik radova sa znanstvenih skupova »Dani Cvita Fiskovića« održanih 2003. i 2004. godine [Zbornik Danā Cvita Fiskovića, sv. 2.], (ur.) Predrag Marković, Jasenka Gudelj, Institut za povijest umjetnosti; Odsjek za povijest umjetnosti Filozofskog fakulteta, Zagreb, 2008., 209-243; usp. i IGOR FISKOVIĆ, Francuski umjetnici u Dubrovniku 16. stoljeća, Hrvatska revija, 12/1-2 (2012.), 156-158.

9 CVITO FISKOVIĆ (bilj. 8, 1964.-1965.), 29-30.

10 Gospodinu Denisu Vokiću zahvaljujem na ustupanju i ljubaznom dopuštenju za objavljivanje fotografija vedute.

11 Državni arhiv u Dubrovniku (dalje: DAD), ser. 25. Diversa Cancellariae, sv. 137, ff. 64v-65v. Ugovor je, u prijepisu Zdravka Šundrice, objavljen u: NADA GRUJIĆ, Kuća u Gradu. Studije o dubrovačkoj stambenoj arhitekturi 15. i 16. stoljeća, Matica hrvatska, Ogranak Dubrovnik, Dubrovnik, 2013., 399-400, a ovdje ga u prilogu ponovno donosimo u integralnom obliku, zajedno s naknadnim pripisom na margini.

12 Ugovori s Ratkom Ivančićem, Živkom Utišenovićem i Radonjom Grubačevićem objavljeni su u: NADA GRUJIĆ, Onofrio di Giordano della Cava i Knežev dvor u Dubrovniku, Renesansa i renesanse u umjetnosti Hrvatske. Zbornik radova sa znanstvenih skupova "Dani Cvita Fiskovića« održanih 2003. i 2004. godine [Zbornik Danā Cvita Fiskovića, sv. 2.], (ur.) Predrag Marković, Jasenka Gudelj, Institut za povijest umjetnosti; Odsjek za povijest umjetnosti Filozofskog fakulteta, Zagreb, 2008., 34.

13 U toj je ulici koja se nazivala Među velike crevljare živio Junijev unuk Benedikt, v. NENAD VEKARIĆ, Vlastela grada Dubrovnika 2. Vlasteoski rodovi A-L, Zavod za povijesne znanosti HAZU, Zagreb-Dubrovnik, 2012., 107. 14 Vlasnik kuće Junije Bona (oko 1529.-1581.) sin je Miha (oko 1487.1530.) - usp. NENAD VEKARIĆ (bilj. 13), 106 - koji je dvadesetih godina 16. stoljeća dao podići ljetnikovac na Batahovini. Prema NADA GRUJIĆ, Vrijeme ladanja. Studije o ljetnikovcima Rijeke dubrovačke, Matica hrvatska, Ogranak Dubrovnik, Dubrovnik, 2003., 19, ljetnikovac BunićKaboga jest »najsjajniji primjer« gotičko-renesansnog stila u ladanjskoj arhitekturi Rijeke dubrovačke.

15 NENAD VEKARIĆ, Vlastela grada Dubrovnika 4. Odabrane biografije (A-L), Zavod za povijesne znanosti HAZU, Zagreb-Dubrovnik, 2013., 106.

16 CVITO FISKOVIĆ (bilj. 8, 1946.-1947.), 18-19; CVITO FISKOVIĆ, (bilj. 8, 1964.-1965.), 29; NADA GRUJĆ (bilj. 11), 48-49. 
17 Annali di Ragusa del magnifico ms. Nicolò di Ragnina, Annales Ragusini anonymi item Nicolai de Ragnina, (prir.) Speratus Nodilo, [Monumenta spectantia historiam Slavorum meridionalium 14, Scriptores 1], Academia scientiarum et artium Slavorum meridionalium, Zagrabiae, 1883., 300-301. Vijest o požaru kuće braće Babalio ujedno je i posljednji zapis u Ragnininoj kronici.

18 Nav. mj.: [...] Del detto anno <1552> si abbrugiò la casa di ms. Giugno, di ms. Lorenzo e di ms. Andrea, fioli di ms. Michele de Bobali, posta sopra li Caligari sopra Lunciariza, con la occasione perche detto ms. Andrea facea convito alla sua sposa, e facendo confetti per detto convito sopra il primo solaro della casa, sáppicciò il fogo alli $18 d$ ' aprile, mercordi a ore 5 di notte. In la qual casa era di robe, de panni Venetiani e di carisie, per valuta < di > più de X millia d<ucati >.; ma tutto, con la massaritia di casa, fu scapulato. [...]

19 Do toga je zaključka moguće doći prelistavanjem knjiga zaključaka gradskih vijeća iz pedesetih i šezdesetih godina; veći je požar, primjerice, izbio 1561. godine u samostanu sv. Klare, v. DAD; ser. 3. Acta Consilii Rogatorum, sv. 55, ff. 226v, 227r, 228r, 233v, 279v.

20 Junije ( $†$ 1585.) i Lovro ( $† 1571$.$) , sinovi Miha Babalija, ostvarili su$ uzorne političke karijere, okrunjene višestrukim izborima na kneževsku čast, v. NENAD VEKARIĆ (bilj. 13), 19.

21 V. ZDENKO ZLATAR, Udio vlastele u dubrovačkoj kreditnoj trgovini (1520-1623), Anali Zavoda za povijesne znanosti HAZU u Dubrovniku, 45 (2007.), 146. Prema ukupnoj vrijednosti trgovačke robe koju su između 1550. i 1572. godine uložili u kreditnu trgovinu, Junije Mihov Babalio i njegov brat Lovro na vrhu su "stogodišnje" liste najvećih dubrovačkih kreditora. 22 Annali di Ragusa del magnifico ms. Nicolò di Ragnina (bilj. 17), 301: [...] Per lo qual incendio la mattina seguente fu gran rumore per la città, perche vensero d' avanti il porto 12 galere Venetiane da Levante. Per la qual causa bisognò far le guardie per la città et attender ad estinguer detto incendio. Et le galere, pigliato lo presente dalla Signoria, se ne partirno alla volta di ponente.

23 Annales Ragusini anonymi (bilj. 2), 109-110: Alla festa di santo Jerolimo, alli 30 di settembre, circa 21 hora di giorno, si apizò il foco in casa d' un prete capelano di Santo Blasio, apresso la chiesa di Santo Stefano [...] talmente che tutta la casa si consumò, dal capo a pie, in dua hore, senza alcun danno alli vicini. Et non fu possibile remover lo fuoco con tutti l' ingegni, fino che tutta fosse consumata. Niente di meno forno morte in quel tempo (in) tutto sette persone dal fuoco et amazate dalla ruina di casa, et molte ferite. Fu grande tremore a Ragusa, perchè quella mattina vensero 10 galere armate di Venetiani, et stettero fino a mezzo giorno avanti lo porto. Dubitavasi non fosse sucesso (l' incendio) per la malitia di alcuni di loro aposta, acioche li cittadini restassero confusi, et loro facessero di notte assalto de Ragusa, per esser signori. In porto di Epitauro stetero parichi giorni, e partirono. Ma cosi fu la divina volontà, senza la quale (non) si può fare cosa alcuna.

24 Annali di Ragusa del magnifico ms. Nicolò di Ragnina (bilj. 17), 301: Di poi mercordì, alli 25 del detto mese, passò lo generale di Dalmatia con 19 galere in fra la città e la Croma; et nel passare saluto la città con molti tiri d' artiglieria, et la città gli fece all' incontro il medesimo dalli castelli, et li mandorno un bel presente.

25 Slanje poklona u hrani i piću mletačkim dužnosnicima i flotama te uzajamno pozdravljanje počasnim topovskim salvama uobičajena je praksa; o propisima u vezi toga u 17. i 18. stoljeću, prema službenom priručniku Cerimoniale, v. NELLA LONZA, Kazalište vlasti. Ceremonijal i državni blagdani Dubrovačke Republike u 17. i 18. stoljeću, Zavod za povijesne znanosti HAZU u Dubrovniku, Zagreb-Dubrovnik, 2009., 184-190 (poglavlje Stranci koji »prohodu« i protokolarna praksa Dubrovačke republike).

26 Primjere i diskusiju v. u: NADA GRUJĆ (bilj. 11), 40, 46, 108-109, 191-193.

27 Dijelovi arhitektonske plastike pročelja - poput ploče balkona koju su nosile naručene četiri masivne dvostruke konzole te ograde (balustrade) središnjega velikog i bočnih manjih balkona - u ugovoru se ne spominju, pa je moguće pretpostaviti da su možda bili sačuvani nakon požara ili su ih, vjerojatnije, braća Babalio nabavila na neki drugi, nezabilježeni način. 28 MAJA NODARI, ZEHRA LAZNIBAT, Ljetnikovac Bobaljević-Pucić u Dubrovniku, Kultura ladanja. Zbornik radova sa znanstvenih skupova
"Dani Cvita Fiskovića održanih 2001. i 2002. godine [Zbornik Danā Cvita Fiskovića, sv. 1], (ur.) Nada Grujić, Institut za povijest umjetnosti; Odsjek za povijest umjetnosti Filozofskog fakulteta, Zagreb, 2006., 221-236.

29 IGOR FISKOVIĆ (bilj. 8, 2008,), 229. Fotografiju grba v. u: NENAD VEKARIĆ (bilj. 13), 16.

30 NADA GRUJIĆ, Reprezentativna stambena arhitektura, Zlatno doba Dubrovnika XV. i XVI. stoljeće, katalog izložbe, MTM, Zagreb, 1987., 68. 31 O srednjovjekovnim općinskim kućama v. DANKO ZELIĆ, Utilitas et lucrum - općinske kuće u srednjovjekovnom Dubrovniku, Umjetnost i naručitelji. Zbornik radova znanstvenog skupa "Dani Cvita Fiskovića» održanog 2008. godine [Zbornik Danā Cvita Fiskovića, sv. 3.], (ur.) Jasenka Gudelj, Institut za povijest umjetnosti; Odsjek za povijest umjetnosti Filozofskog fakulteta, Zagreb, 2010., 9-24.

32 Prema matičnoj knjizi općinskih nekretnina - usp. Knjige nekretnina (bilj. 4), II, 155-158 - kuće s dućanima četvrtog bloka posljednji su put iznajmljene 1551., odnosno 1556., a potom je u rubrikama upisano samo: bruxiata.

33 Die VIII februarii 1559 iovis.

Prima pars est de providendo quod scopulum in Platea magna positus et incendio consumptus fabricari debeat et postea dicetur quomodo. Per omnes, contra 1.

Prima pars est de ordinando quod quando dictus scopulus fabricabitur domus fabricari debeat cum voltis et fornicibus et super fornicis compleri domus debeant et ante scopulum fabricari debeat porticus cum columnis ad similitudinem porticus facti per Iacobum Gallibertum. Per omnes, contra IIII. (DAD, ser. 3. Acta Consilii Rogatorum, sv. 54, f. 232v).

34 [Die IIII maii 1556] Illustrissimi signori, io Iacobo Galliberto gia fatto cittadino di questa citta per gratia e privilegio de vostre illustrissime signorie e per l'habitatione mia di cotanto tempo come quello chi penso e delibero di finire qui gli anni miei e ad fine lassomi lossa, desidererebbi non gia per me solo, ma anche per alcuni miei compagni ragusei desser accomodato per vinticinque anni di tutto el scacco del comune con le sue quattro botteche vicino alla dohana e per dimostrare che io risguardo, cussi bene al utilita et ornamento pubblico come al proprio commodo, offerisco questo partito di fabricarci alle mie spese per faccia una volta sostenuta da colonne di pietra dal un cantone del scacco ad altro, alto e largo e di quello lavoro secondo el dissegno el quale con questa si presenta a vostre illustrissime signorie purche el mi sia concesso tutto per ducento quaranta iperperi al anno per ditto tempo e suono contento che finiti li vinticinque anni, el scacco ritorni al commune con tutti gli meglioramenti si della volta come di tutti gli altri fatti lavori senza pagamento nesuno. Supplico adumque con humilta e reverenza vostre illustrissime signorie a farme degno di questo partito, offerendo a compire la volta fra uno anno al piu tardi e parendo a quelli che la volta si facesse d' un' altro dissegno e modello me ne contenta remaner al giudicio loro, alli quali di cuore mi raccomando. (DAD, ser. 3 . Acta Consilii Rogatorum, sv. 53, f. 197r)

35 Godine 1561. dvije kuće s dućanom koje su (spojene) činile polovicu šestog bloka (do crkve Petilovrijenci), iznajmljene su na 20 godina poznatom dubrovačkom spičaru (apotekaru) Roku Fasanu, a on se zauzvrat obvezao involtare tutta la botegha e far gli archi di quella a tutte sue spese, usp. Knjige nekretnina (bilj. 4), II, 168. Čini se da ti archi di botegha ipak nisu bili lukovi vanjskog trijema, nego konstrukcije izvedene na mjestu dotadašnjega pregradnog zida kojim su dva prostora dućana bila spojena u jedinstvenu cjelinu.

36 Takav zaključak potvrđuju neprekinuti sljedovi upisa najmova općinskih kuća u knjigama općinskih nekretnina tijekom 15. i prve polovine 16. stoljeća, usp. Knjige nekretnina (bilj. 4), I, 185-193, 286-295; II, 129-169.

O intenzitetu radova na popravcima i održavanju građevina u općinskom vlasništvu svjedoči, primjerice, jedna od rijetkih sačuvanih knjiga rashoda koje su vodili službenici zaduženi za javne gradnje - DAD, ser. VII. Fabbriche, sv. 3, Lavorieri del Comun 1562. U godini dana u njoj je evidentiran ukupno 391 stavak s isplatama vezanim uz različite zahvate na zidinama, mlinovima, upravnim zgradama, općinskim kućama itd. 37 Trijemovi pred općinskim ali i drugim kućama na Placi razabiru se već na najstarijem sačuvanom prikazu - veduti Dubrovnika u rukama 
sv. Vlaha na reljefnom liku gradskog zaštitnika u crkvi sv. Vlaha. Crtež čiji detalj reproduciramo objavljen je u: MILAN REŠETAR, Slike starog Dubrovnika, Narodna starina, III/8 (1924.), 178.

38 [Die primo iulii 1556] Magister Antonius de Costa de Curzula lapicida ibi presens sponte convenit cum domino Iacobo Galliberto de Barulo habitatore Racusii de sibi laborando petras pro quattuor arcubus quos intendit facere ante quattuor apothecas quas ipse cum sociis a communi conduxit prope fundicum dohanae, quae petrae debeant esse laborate sicut apparet in dissegno facto et subscripto manu Petri Francisci Parisii notarii, dando operam que petre sint bone et pulchre ut laborerium commenditur a peritis et conventuum fuit quod dictus dominus Iacobus teneatur predicto magistri Antonio pro toto opere predicto dare et solvere scutatos auri sexaginta pro parte quorum statim confessus fuit se habuisse scutatos auri quindecim cum pacto quod dictus magister Antonius teneatur conducere Racusium dictum laborerium per totum decembrum proxime futurum. Renunciando. (DAD, ser. 26. Diversa notarie, sv. 115, f. 28v)

Isti je ugovor, zacijelo zabunom notara, s tek neznatnim razlikama u stilizaciji teksta, ponovno $\mathrm{u}$ istoj knjizi registriran pod nadnevkom 1. kolovoza, na f. 39r.

Korčulanski klesar Antun Costa djelovao je u drugoj polovini 16. stoljeća ne ostavivši u dokumentarnoj građi tragova koji bi privukli pozornost povjesničara umjetnosti. Kao jedan od najvažnijih protagonista herojske obrane Korčule od napada otomanske flote 1571. godine (jedini pučanin među četiri izabrana vojna zapovjednika), Antun se spominje u kroničarskom zapisu korčulanskog arhiđakona Antuna Rozanovića. U opsadi je smrtno stradao njegov sin Frane koji je na vijest o približavanju neprijatelja "pješice došao iz Dubrovnika " gdje je radio kao klesar, v. ANTUN ROZANOVIĆ, Obrana Korčule od Turaka god. 1571., (prir.) Ivo Matijaca, Opatsko-nadžupni ured, Korčula, 1971., 15, 27.

39 Porticum totum ante fonticum obvezali su se 1518. godine isklesati Nikola Blažev i Josip Markov Andrijići; ugovor je objavio CVITO FISKOVIĆ, Dokumenti o radu naših graditelja i klesara XV-XVI stoljeća u Dubrovniku, Izdanje Konzervatorskog zavoda u Splitu, 3 (1947.), 24-25, bilj. 69.

40 Kuće s dućanima u šest blokova do Sponze bile su komercijalno najatraktivniji dio fonda općinskih nekretnina; o tome svjedoče visine iznosa godišnjih najmova, ali i zakon iz 1449. (Ordo super stationibus platearum) kojim je propisano da se ubuduće ne smiju davati u najam obrtnicima manualnih struka, nego isključivo trgovcima, opširnije u: DANKO ZELIĆ (bilj. 31), 16.

41 DAD, ser. 36.b. Debita Notariae pro comuni, sv. 1, ff. 147v-148r. Na ugovor je, kao što je rečeno, prvi upozorio CVITO FISKOVIĆ (bilj. 7), 60 , gdje mu se potkralo nekoliko pogrešaka koje su u kasnijim radovima ispravljene: godina je (umjesto 1559.) prepisana kao 1550., pretpostavljeno je da se via larga (umjesto na Placu) odnosi na Široku ulicu, a prezime oficijala koji je sklopio ugovor s majstorima prenijeto je kao Bunić, premda je posrijedi Caboga.

42 Okviri starijih vrata "na koljeno" na kućama na Placi zamjenjivani su tijekom vremena običnim, lučno završenim okvirima (bez "koljena"). Drži se da je do tih promjena došlo u 19. stoljeću; otud i kolokvijalan naziv za njih - »austrijski«. Konzervatorska praksa u drugoj polovini 20. stoljeća težila je (i uspjela) da znatan broj tih okvira, među inima i dvoja vrata na četvrtom bloku, bude restituiran u starijem obliku.

43 CVITO FISKOVIĆ (bilj. 7), 60; LUKŠA BERITIĆ (bilj. 1), 29.

44 Pomisao da je bila riječ o dva bloka - s obzirom na formulaciju u prvom ugovoru (fabrica duarum domuum comunis combustarum) - otklanja neprekinuti slijed evidentiranja najmoprimaca u matičnoj knjizi općinskih nekretnina; preostalih pet blokova ne pokazuje diskontinuitet. 45 Sve su dimenzije u ugovoru iskazane u laktima, a metričku protuvrijednost te mjerne jedinice ovom prigodom zaokružujemo na $0,5 \mathrm{~m}$. Prilog diskusiji o točnoj, apsolutnoj, duljini dubrovačkoga "građevinskog" lakta v. u tekstu Gorana Nikšića u ovom Zborniku.

46 NADA GRUJIĆ (bilj. 11), poglavlje Kuća Bona na Bunićevoj poljani, 223-227. Od izvornog para prozora (grafička rekonstrukcija u nav. dj. na str. 224), danas je sačuvan samo jedan.

47 Na pomisao da su (i) u tu kuću bila investirana prilično velika sredstva navodi činjenica da su Junije i Marin, sinovi Benedikta Restija, po- put braće Babalio o kojima je bilo riječi u prvom dijelu priloga, također pripadali najužoj političkoj i gospodarstvenoj eliti grada, v. NENAD VEKARIĆ, Vlastela grada Dubrovnika 3. Vlasteoski rodovi (M-Z), Zavod za povijesne znanosti HAZU, Zagreb-Dubrovnik, 2012., 224; usp. i ZDENKO ZLATAR (bilj. 21), 153.

48 Odabir Kristofora Caboge za tu zadaću zacijelo se zasnivao na referencijama proizašlim iz njegova ranijeg sudjelovanja u javnim gradnjama. Primjerice, početkom 1552., u jeku priprema za velike zahvate na obalnom potezu gradskih zidina - usp. LUKŠA BERITIĆ, Utvrđenja grada Dubrovnika, Odjel za likovne umjetnosti JAZU, Zagreb, 1955. 147-149 - u Vijeću umoljenih izabran je (s najviše glasova) kao jedan od četvorice oficijala laboreriorum fabricae moniorum civitatis, v. DAD, ser. 3. Acta Consilii Rogatorum, sv. 51, ff. 8v-9r.

49 Knjige nekretnina (bilj. 4), II, 298-299. CVITO FISKOVIĆ (bilj. 8, 1964.-1965.), 30, 37, upozorio je na dva dokumenta koja govore o tome da je nakon završetka posla na četvrtom bloku između Ivana Stjepanova i Spinisa došlo do prijepora koji su trebali razriješiti suglasno imenovani pomirbeni suci; Spinis je za postupak arbitraže predložio magistra Petra Kotoranina, a Ivan Nikolu, sina spominjanoga korčulanskog kamenara Antuna Coste. Kao Spinisov je jamac u sporu zabilježen treći član skupine klesara - Jeronim Bartolomejev Lombardijac.

50 Svodove su (dobrim dijelom sačuvane do danas), prema standardu uspostavljenom u (prvoizgrađenim) kućama u kojima su smještene radionice zlatara i kovača, imali svi lokali u prizemljima dvostrukih nizova općinskih kuća ispod ulice Prijeki, v. DANKO ZELIĆ (bilj. 31), 18-19.

51 Tlocrtne dimenzije blokova općinskih kuća na Placi bile su 13-14x7$7,5 \mathrm{~m}$.

52 Iz popisa arhitektonskih elemenata klesanih za interijere ne mogu se izvoditi širi zaključci, jer su neki elementi unutrašnje opreme možda u požaru ostali pošteđeni. Ipak, kada su posrijedi tri stubišta, treba upozoriti da su - prema zapisima u knjigama općinskih nekretnina, za razliku od ostalih pet blokova (podijeljenih na po četiri kuće s pripadajućim dućanima) - dvije kuće na istočnoj strani četvrtog bloka prije 1417. godine spojene u jednu cjelinu (kuću s dva dućana u prizemlju), usp. Knjige nekretnina (bilj. 4), I, 190-191. To znači da je blok sadržavao tri funkcionalne cjeline. Ta se podjela, dakako, nije odrazila na pročelju (s otvorima simetrično raspoređenim u četiri osi), premda treba upozoriti da se u prvom ugovoru (iz 1559., s korčulanskim majstorima) poslije tri prozora prvog kata spominju vrata, jednako obrađenog i ukrašenog okvira. Vrata su možda bila predviđena za izlazak na terasu nad trijemom, no takvo bi rješenje, međutim, upućivalo na pomisao da je cijeli stambeni prostor na katovima prema prvotnom projektu obnove bio zamišljen kao jedinstvena cjelina, što je - s obzirom na korištenje ravnog krova nad trijemom kao terase - vjerojatno impliciralo i postavljanje ograde/balustrade.

53 CVITO FISKOVIĆ, O starim dalmatinskim kaminima, Bulletin Razreda za likovne umjetnosti Jugoslavenske akademije znanosti i umjetnosti, 1 [51] (1981.), 58; o razlikama između (starijih) kamina ad usum Venetum i onih (novijih) alla francese v. NADA GRUJIĆ (bilj. 11), 285.

54 NADA GRUJIĆ, Dialogue Gothique-Renaissance dans l'architecture ragusaine des $X V^{e}$ et $X V I^{e}$ siècles, Le Gothique de la Renaissance [Collection 'De architectura, fondée par André Chastel et Jean Guillaume], (ur.) Monique Chatenet et al., Picard, Paris, 2011., 121-134.

55 NADA GRUJIĆ (bilj. 11), 89.

56 Parafraziramo, naravno, naslov teksta NADA GRUJIĆ, Kuća savršenog trgovca po Benediktu Kotruljeviću (Kotrulju), Dubrovnik, 6/4 (1995.), 198-212, objavljenog i u NADA GRUJIĆ (bilj. 11), 147-157.

U svom traktatu, usp. ZDENKA JANEKOVIĆ RÖMER, Libro del arte dela mercatura/Knjiga o vještini trgovanja, Zavod za povijesne znanosti HAZU u Dubrovniku; Hrvatski računovođa, Zagreb-Dubrovnik, 2009., glasoviti dubrovački petnaestostoljetni teoretičar (i praktičar) "merkantologije" nije pisao o dubrovačkim općinskim kućama, ali njegovo ime, zajedno s imenima bezbrojnih protagonista gospodarskog života grada, nalazimo zapisano u matičnim knjigama općinskih nekretnina, v. Knjige nekretnina (bilj. 4), I, 288, među najmoprimcima općinskih kuća na Placi. Benedikt Kotrulj je, zajedno s partnerom Marinom Ruiom, na dražbi 1449. godine na pet godina unajmio drugu kuću drugog bloka od Sponze. 
Summary

\section{Danko Zelić}

Two Fires, Two Renewals, Two Styles: a Contribution to the Knowledge of 16th Century Residential Architecture of Dubrovnik

Starting from primary/archival documents and data from narrative and pictorial sources, i.e. the writings of local historians and a veduta of Dubrovnik before the Great earthquake of 1667, the author analyzes the evidence concerning renewals of two buildings in the sixth decade of the 16th century, both located in the very centre of the town of Dubrovnik.

Two renewal campaigns were caused by fires and the main contractor in both of them was Jacob Spinis (magister Iacobus de Spinis de Orliens Gallus lapicida), a stonemason of French origin who came to Dubrovnik from Venice in 1552 and stayed for at least twelve years. The architectural styles chosen for the sculptural decoration of the facades of the house of Babalio brothers and the fourth block of communal houses on the main street was, however, different: Gothic for the former and Renaissance for the latter.

The facade of the Babalio brothers house (restored in 1552) had three rows of symmetrically arranged windows. Six smaller window frames, commissioned for the "secondary floors", were to be replicas of the windows on the first floor of Rector's Palace. The principal floor wall area-corresponding to the great hall (sala) in the interior-was pierced by richly decorated Flamboyant Gothic openings of considerable dimensions: a $5 \mathrm{~m}$ high and $3 \mathrm{~m}$ wide triple mullioned central window flanked by a pair of single windows of equal height on either side with statues on top of them. In front of the piano nobile openings were three balconies, the central resting upon four strong double console brackets of carved stone.

The post-fire renewal of the fourth block of communal houses, initially, in 1559, conceived as a restoration turned out to be a complete reconstruction. As one of the six blocks of communal houses built in the second half of the 14th century, the building, although of unified external appearance, had an interior that was divided into four equal three-storey units, the so-called case e staçoni (houses with shops), regularly lent to merchants for five-years terms at the periodic public auctions.

In 1559 a vaulted stone portico with five columns was added along the facade of the block, replacing thus the older one, presumably made of wood and covered with terracotta roof tiles. The project also envisaged the stone vaulting over the four shops at ground-level, a decision not primarily taken for the reasons of building statics, but as a measure of fire prevention.

As the contract of 1559 shows, the openings of the first floor were to be smaller than those of the second floor, accordingly to the then height of the respective storeys. However, the interior vertical division, i.e. the floor levels, was subsequently altered, which resulted in the changes of the initial facade scheme. Two years after the first contract the municipal officials in charge commissioned from Jacob Spinis and his partners various masonry items for the building, including four larger windows. Their description in the contract of 1561 as fenestre quattro alla romana con suoi frontispicii di sopra, con meze collone d'attorno, con li cartoni corresponds well with the actual first floor windows, apart from the fact that the frontispicii (pediments) were probably never executed. The smaller second floor windows, however, although not mentioned in the archival documents, were arguably commissioned at the same time as well. Consequently, the author proposes that not only the design of the first floor windows should be attributed to Jacob Spinis, but also of those on the second floor, as well as probably the windows on a house belonging to brothers Resti, referred to in the contract of 1561 as the models for the first floor openings.

The preliminary research results also speak in favour of the hypothesis that Spinis' facade of the fourth block served as a prototype for the fronts of buildings made along the Dubrovnik's main street (Placa) during the 17th century, before, but also after the Great earthquake and conflagration of 1667. 